\title{
EFEK ANTIINFLAMSI GEL KACANG HIJAU PADA MENCIT PUTIH (Mus musculus)
}

\author{
Rulia Meilina*1, Suwita Afriana ${ }^{2}$ \\ a Universitas Ubudiyah Indonesia, Banda Aceh, Indonesia \\ b Universitas Ubudiyah Indonesia, Banda Aceh, Indonesia \\ *koresponding Penulis : ${ }^{1}$ (rulia.meilina@ uui.ac.id), ${ }^{2}$ (suwitaafriana98@gmail.com)
}

\begin{abstract}
Abstrak
Kacang hijau sebagai bahan makanan manusia cukup baik dikonsumsi untuk memenuhi kebutuhan gizi dan kesehatan tubuh, karena di samping kaya protein, juga mengandung zat-zat gizi lainnya yang cukup lengkap. Penelitian mengenai kacang hijau sebelumnya menyatakan bahwa kacang hijau mengandung senyawa metabolit sekunder diantaranya, flavonoid, tanin, steroid/triterpenoid, dan saponin yang berpotensi sebagai antioksidan. Metode yang digunakan dalam penelitian ini ialah metode eksperimental, meliputi pengumpulan tumbuhan, pengolahan dan pengujian sampel, pembuatan dan pengujian sediaan terhadap hewan coba sampai dengan analisis data statistik. Hasil persentase perhitungan dari pengurangan perubahan diameter pada luka sayat diperoleh efektivitas penyembuhan luka yang sangat baik pada betadin salep sebagai kontrol positif, sediaan gel ekstrak 10\%, ekstrak 7.5\% dan tanpa ekstrak (kontrol negatif), dan ekstrak 5\%. Penyembuhan luka di mulai pada hari ke- 8 sampai ke-21 untuk kontrol gel ekstrak 10\%. Penyembuhan luka pada hari ke-13 sampai ke-23 untuk gel ekstrak 7.5\% dan tanpa ekstrak. Penyembuhan luka pada hari ke-13 sampai ke-24 untuk betadin salep. Penyembuhan luka pada hari ke-13 sampai ke-25 untuk gel ekstrak 5\%. Berdasarkan hasil pengamatan selama penelitian hewan uji, bahwa pada ekstrak 10\% lebih cepat mengalami masa penyembuhan dibanding dengan sampel pembanding yaitu betadin salep sebagai kontrol positif.
\end{abstract}

\begin{abstract}
ABTSRACT
A small ground mung beans as human food is very good to be consumed to fulfill the need of essence to keep body healthy because it not only contains rich protein but also has the other complete nutrient assent. The experient before about mung beans have contains secondary metabolites the flavonoid, tannin, steroid/triterpenoid, and saponin are effect for antioxidant. The purpose of the research is to know the activity of antioxidant from mung beans ethanol extraction, the process of ethanol extraction mung beans formulation in gel form, and the effect of anti-inflammation healing the cut on the body of mice. Presentation result of counting on reducing the change of cut diameter it is found that the process of healing cut is very good for betadine salve, the extraction gel $10 \%$, gel $7.5 \%$, without extraction and gel $5 \%$. To control the extraction gel $10 \%$, it is necessary to know that the cut healing start from the eighth to the twenty-first day, to control gel $7.5 \%$ without extraction it is also important to know that the cut healing starts from the thirteenth to the twenty-third day. The cut healing on the day of the thirteenth until on the day of the twentyfourth is for betadine salve. The cut healing on the of the thirteenth until on the day of the twenty-fifths is for extraction gel $5 \%$.
\end{abstract}

Keyword: Anti-inflammation, mung beans (Vigna radiata L.), Gel, Antioxidant

\section{PENDAHULUAN}

Kulit adalah sistem yang paling luas dan paling berat dari tubuh, kulit berfungsi untuk menjaga jaringan internal dari trauma, bahaya radiasi sinar ultra-violet, temperatur yang ekstrim, toksin dan bakteri (Maryuni, 2013). Luka sayat merupakan suatu bentuk kerusakan atau kehilangan jaringan tubuh yang disebabkan oleh 
benda tajam. Luka sayat merupakan jenis luka akut. Luka sayat dapat menimbulkan pendarahan yang melibatkan peran hemostatis dan akhirnya terjadi peradangan. Gangguan terhadap kulit seperti luka akan mempengaruhi fungsi kulit. Luka merupakan hilang atau rusaknya sebagian jaringan kulit yang dapat disebabkan oleh trauma tajam atau tumpul, perubahan suhu, zat kimia, ledakan, sengatan listrik, atau gigitan hewan (Ningsih, dkk., 2015).

Antioksidan adalah senyawa kimia yang dapat digunakan untuk melindungi komponen biologi seperti lipida, protein, vitamin dan DNA melalui perlambatan kerusakan, ketengikan atau perubahan warna yang disebabkan oleh oksidasi (Moniharapon, dkk 2016). Aktivitas antioksidan yang berasal dari makanan dan masuk di dalam tubuh, sangat tergantung dari jumlah zat yang dapat diserap dan digunakan untuk proses metabolisme. Vitamin E mempunyai efek pencegahan terhadap penyakit kardiovaskular karena vitamin E dapat melindungi asam lemak tak jenuh ganda terhadap kerusakan oksidatif dalam membran sel. Salah satu bahan pangan yang sangat populer di Indonesia yaitu kecambah kacang hijau (Novidiyanto, dkk., 2016).

Kacang hijau merupakan salah satu jenis kacang yang cukup banyak dikonsumsi masyarakat sebagai makanan fungsional. Berdasarkan penelitian sebelumnya mengenai kacang hijau, diketahui kacang hijau mengandung senyawa metabolit sekunder diantaranya, flavonoid, tanin, steroid/triterpenoid, saponin yang berpotensi sebagai antioksidan (Moniharapon, dkk., 2016).

\section{METODE PENELITIAN}

Metode yang digunakan dalam penelitian ini ialah metode eksperimental, meliputi pengumpulan tumbuhan, pengolahan dan pengujian sampel, pembuatan dan pengujian sediaan terhadap hewan coba sampai dengan analisis data statistik.

\section{Alat Dan Bahan Penelitian}

Alat yang digunakan ialah rotary evaporator, pipet ukur, timbangan analitik, spektrofotometri UVVisibel, pengaduk, labu ukur, krus porselin, lampu pijar, cawan penguap, tabung reaksi, lumpang, viskometer, $\mathrm{pH}$ meter, pinset, dan kandang mencit.

Bahan yang digunakan ialah Kacang hijau, betadine salep, etanol 96\%, DPPH (1,1-difenil-2pikrilhidrazil), asam klorida $(\mathrm{HCl})$, kloroform, pereaksi Wagner, pereaksi Dragendroff, pereaksi Mayer, $\mathrm{NaCl}$ $10 \%, \mathrm{FeCl} 1 \%$, asam sulfat pekat, HPMC (Hidroxy Propyl Methyl Cellulose), Propilen glikol, Metil Paraben, propil Paraben, aquades, dan eter.

\section{Skrining Fitokimia}

kacang hijau diperoleh di pasar peunayong, Banda Aceh dan identifikasi di MIPA Biologi Universitas Syiah. Kuala. Skirining fitokimia simplisia kacang hijau meliputi alkaloid, flavonoid, tannin, saponin, glikosida dan steroid dan triterpenoid.

\section{Pembuatan ekstrak}

kacang hijau dikeringkan dengan di lemari pengering dengan suhu 30-35 $\mathrm{C}$ kemudian dilakukan ekstraksi dengan metode maserasi menggunakan pelarut etanol 95\% sehingga diperoleh ekstrak etanol kacang hijau.

\section{Pengujian antioksidan}

Pengujian antioksidan ekstrak kacang hijau dilakukan dengan metode DPPH.

\section{Rancangan Dan Pembuatan Formula Gel}

Tabel 1. Rancangan formula gel ekstrak kacang hijau

\begin{tabular}{|c|c|c|c|c|c|}
\hline \multirow{2}{*}{ Bahan } & \multirow{2}{*}{ Kegunaan } & \multicolumn{4}{|c|}{ Formulasi/Konsentrasi (\% b/b) } \\
\cline { 3 - 6 } & & I & II & III & IV \\
\hline Ekstrak kacang hijau & Bahan Aktif & 5 & 7,5 & 10 & - \\
\hline HPMC & Gelling Agent & 5 & 5 & 5 & 5 \\
\hline Propilen glikol & Penstabil, Peningkat, penetrasi & 15 & 15 & 15 & 15 \\
\hline Metil Paraben & Humektan & 0,075 & 0,075 & 0,075 & 0,075 \\
\hline Propil Paraben & Pengawet & 0,025 & 0,025 & 0,025 & 0,025 \\
\hline Air Suling & Pembawa & Ad 100 & Ad 100 & Ad 100 & Ad 100 \\
\hline
\end{tabular}

HPMC (Hidroxy Propyl Methyl Cellulose) didispersikan dalam aquades yang sudah dipanaskan hingga suhu 80-90 lalu digerus hingga terbentuk dispersi yang homogen di dalam lumpang. Metil paraben dan Propil paraben dilarutkan dalam propilen glikol, kemudian ditambahkan ekstrak etanol kacang hijau (Campuran 1). Campuran 1 ditambahkan sedikit demi sedikit ke dalam HPMC yang telah dikembangkan disertai dengan 
pengadukan hingga homogen. Sisa air ditambahkan sambil terus diaduk. Gel dihomogenkan, kemudian diisikan ke dalam pot-pot plastic (Fajrina, 2017).

\section{Penggujian Stabilitas}

Pengujian stabilitas meliputi pemeriksaan stabilitas fisik, pemeriksaan homogenitas, penentuan $\mathrm{pH}$, dan penentuan viskositas sediaan.

\section{Prosedur Pengujian Efektivitas Anti-Inflamasi}

Mencit dibagi ke dalam 5 kelompok perlakuan yaitu pengujian kontrol negatif, pengujian bahan uji (konsentrasi gel ekstrak etanol kacang hijau 5\%, 7,5\% dan 10\%) dan pengujian kontrol positif (Betadine salep). Pada hari pengujian, terlebih dahulu dicukur bulu bagian punggung mencit kemudian dianestesi dengan menggunakan eter, selanjutnya dibuat luka berbentuk lingkaran diameter $\pm 1,5 \mathrm{~cm}$ dengan kedalaman $0.2 \mathrm{~cm}$ sesuai dengan ukuran tanda yang telah dibuat. Mencit dilukai dengan cara mengangkat kulit hewan uji dengan pinset dan disayat dengan bantuan pisau dan gunting yang telah dibersihkan dengan alkohol. Pemberian sediaan gel dilakukan secara topikal sebanyak satu kali sehari. Data dianalisis secara statistik.

\section{HASIL DAN PEMBAHASAN}

\section{Skrining fitokimia simplisia kacang hijau}

Tabel 2. Hasil skrining fitokimia simplisia kacang hijau

\begin{tabular}{lc}
\hline \multicolumn{1}{c}{ Kandungan senyawa metabolit } & Hasil \\
\hline Flavanoid & + \\
Saponin & + \\
Tanin & + \\
Steroid/triterpenoid & + \\
Glikosida & - \\
\hline Alkaloid & + \\
\hline
\end{tabular}

\section{Aktivitas antioksidan}

Tabel 3 .Hasil aktivitas antioksidan ekstrak etanol kacang hijau (Vigna radiata L.)

\begin{tabular}{|c|c|c|c|}
\hline Kosentrasi (ppm) & Absorbansi rata-rata & \% Inhibisi & $\mathrm{IC}_{50}(\mathrm{ppm})$ \\
\hline 20 & 0,155 & 0,64 & \multirow{5}{*}{129,09} \\
\hline 40 & 0,115 & 26,28 & \\
\hline 60 & 0,107 & 31,41 & \\
\hline 80 & 0,104 & 33,33 & \\
\hline 100 & 0,104 & 33,33 & \\
\hline
\end{tabular}

Kurva hubungan kosentrasi sampel terhadap persen inhibisi sebagai persen penghambat radikal bebas DPPH dari ekstrak etanol dapat dilihat pada gambar dibawah ini.

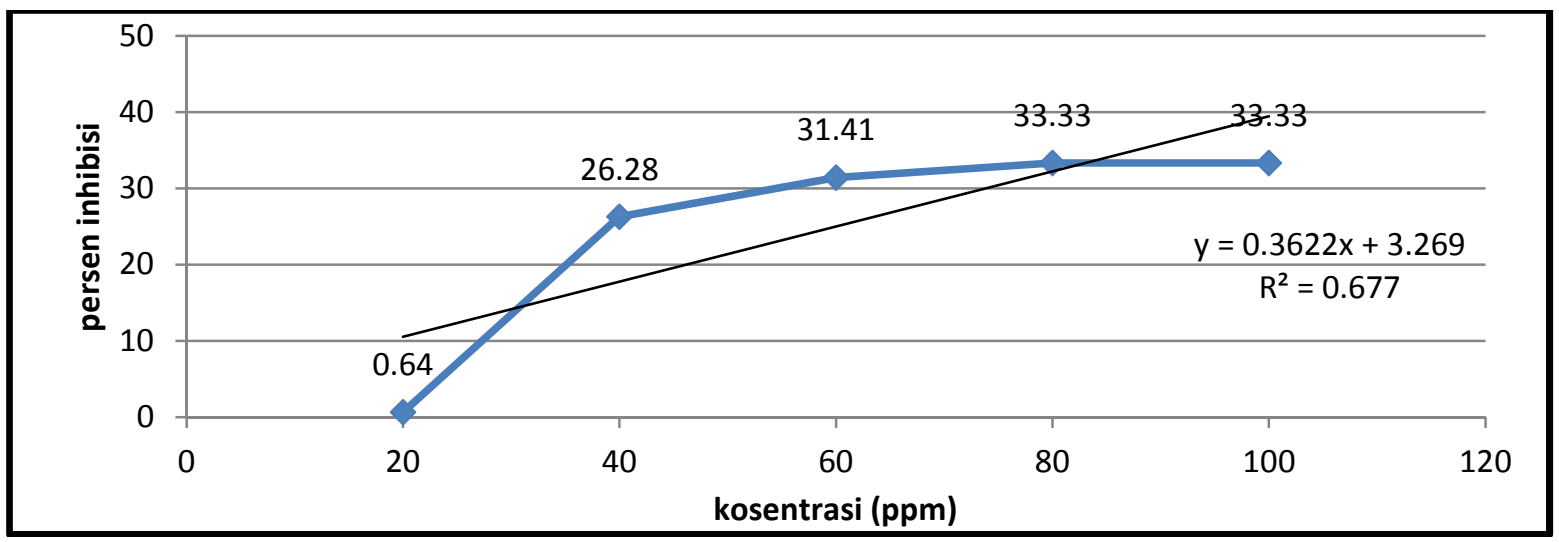

Gambar 1. Kurva hubungan konsentrasi dan persen inhibisi ekstrak etanol kacang hijau (Vigna radita L.) 
Journal of Healthcare Technology and Medicine Vol. 5 No. 2 Oktober 2019

Universitas Ubudiyah Indonesia

e-ISSN : 2615-109X

Berdasarkan hasil perhitungan $\mathrm{IC}_{50}$ menunjukkan bahwa ekstrak etanol kacang hijau memiliki aktivitas antioksidan dengan nilai $\mathrm{IC}_{50}$ sebesar $129,09 \mathrm{ppm}$ yang secara spesifik tergolong antioksidan dengan kemampuan sedang karena bernilai 100-150 ppm. Semakin kecil IC $_{50}$ berarti semakin tinggi aktivitas antioksidan (Moniharapon, dkk., 2016).

\section{Evaluasi Gel Ekstrak Etanol Kacang Hijau (Vigna radiata L.)}

\section{Pengamatan Organoleptik Sediaan}

Tabel 4. Hasil pengamatan organoleptik sediaan

\begin{tabular}{|c|c|c|c|c|c|c|}
\hline \multirow{2}{*}{ Formula } & \multirow{2}{*}{ Organoleptik } & \multicolumn{5}{|c|}{ Lama pengamatan } \\
\hline & & Awal & 1 & 2 & 3 & 4 \\
\hline \multirow{4}{*}{ I } & Bentuk & $\mathrm{B}$ & B & B & $\mathrm{B}$ & $\mathrm{B}$ \\
\hline & Warna & - & - & - & - & - \\
\hline & Rasa & $\mathrm{P}$ & $\mathrm{P}$ & $\mathrm{P}$ & $\mathrm{P}$ & $\mathrm{P}$ \\
\hline & Bau & - & - & - & - & - \\
\hline \multirow{4}{*}{ II } & Bentuk & $\mathrm{B}$ & $\mathrm{B}$ & $\mathrm{B}$ & $\mathrm{B}$ & $\mathrm{B}$ \\
\hline & Warna & KK & KK & KK & KK & KK \\
\hline & Rasa & $\mathrm{P}$ & $\mathrm{P}$ & $\mathrm{P}$ & $\mathrm{P}$ & $\mathrm{P}$ \\
\hline & $\mathrm{Bau}$ & $\mathrm{K}$ & $\mathrm{K}$ & $\mathrm{K}$ & $\mathrm{K}$ & $\mathrm{K}$ \\
\hline \multirow{4}{*}{ III } & Bentuk & $\mathrm{B}$ & $\mathrm{B}$ & $\mathrm{B}$ & $\mathrm{B}$ & $\mathrm{B}$ \\
\hline & Warna & KK & KK & KK & KK & KK \\
\hline & Rasa & $\mathrm{P}$ & $\mathrm{P}$ & $\mathrm{P}$ & $\mathrm{P}$ & $\mathrm{P}$ \\
\hline & $\mathrm{Bau}$ & $\mathrm{K}$ & $\mathrm{K}$ & $\mathrm{K}$ & $\mathrm{K}$ & $\mathrm{K}$ \\
\hline \multirow{4}{*}{ IV } & Bentuk & $\mathrm{B}$ & B & $\mathrm{B}$ & $\mathrm{B}$ & $\mathrm{B}$ \\
\hline & Warna & $\mathrm{CK}$ & CK & $\mathrm{CK}$ & $\mathrm{CK}$ & CK \\
\hline & Rasa & $\mathrm{P}$ & $\mathrm{P}$ & $\mathrm{P}$ & $\mathrm{P}$ & $\mathrm{P}$ \\
\hline & $\mathrm{Bau}$ & $\mathrm{K}$ & $\mathrm{K}$ & $\mathrm{K}$ & $\mathrm{K}$ & $\mathrm{K}$ \\
\hline
\end{tabular}

Keterangan : Formula I (tanpa ekstrak), II (ekstrak 5\%), III (ekstrak 7,5\%), dan IV (ekstrak 10\%), B = baik/stabil, $\mathrm{KK}=$ kuning kecokelatan, $\mathrm{CK}=$ cokelat kekuningan, $\mathrm{P}=$ pahit, $\mathrm{K}=$ khas ekstrak.

Berdasarkan hasil pengamatan organoleptik formulasi sediaan gel selama 4 minggu terhadap basis gel tidak mengamali perubahan bentuk, warna, rasa, dan bau secara visual. Sediaan gel di nyatan tidak stabil bila tidak terdapat perubahan yang signifikan pada parameter yang diamati (Fajrina, 2017).

\section{Pengamatan Homogenitas Sediaan}

Tabel 5. Hasil pengamatan homogenitas sediaan

\begin{tabular}{|c|c|c|c|c|c|}
\hline \multirow{2}{*}{ Formula } & \multicolumn{5}{|c|}{ Hasil pengamatan (minggu) } \\
\cline { 2 - 5 } & Awal & $\mathbf{1}$ & $\mathbf{2}$ & $\mathbf{3}$ & $\mathbf{4}$ \\
\hline I & $\mathrm{H}$ & $\mathrm{H}$ & $\mathrm{H}$ & $\mathrm{H}$ & $\mathrm{H}$ \\
\hline II & $\mathrm{H}$ & $\mathrm{H}$ & $\mathrm{H}$ & $\mathrm{H}$ & $\mathrm{H}$ \\
\hline III & $\mathrm{H}$ & $\mathrm{H}$ & $\mathrm{H}$ & $\mathrm{H}$ & $\mathrm{H}$ \\
\hline IV & $\mathrm{H}$ & $\mathrm{H}$ & $\mathrm{H}$ & $\mathrm{H}$ & $\mathrm{H}$ \\
\hline
\end{tabular}

Keterangan : Formula I (tanpa ekstrak), II (ekstrak 5\%), III (ekstrak 7,5\%), dan IV (ekstrak 10\%), H = homogen.

Hasil pemeriksaan homogenitas sediaan yang dilihat secara visual dengan hasil pengujian semua formula tidak mengalami perubahan warna dan tidak ditemukan partikel di dalamnya. Pemeriksaan homogenitas bertujuan untuk melihat penyebaran zat aktif dalam sedian gel (Fajrina, 2017).

\section{Pengujian pH Dan Viskositas Sediaan}

Tabel 6. Hasil pengujian $\mathrm{pH}$ dan viskositas sediaan

\begin{tabular}{|c|c|c|}
\hline Formula & pH & Viskositas (Pa) \\
\hline I & 6 & 21,98 \\
\hline II & 6 & 22,66 \\
\hline III & 6 & 22,71 \\
\hline IV & 6 & 23,90 \\
\hline
\end{tabular}

Keterangan : Formula I (tanpa ekstrak), II (ekstrak 5\%), III (ekstrak 7,5\%), dan IV (ekstrak 10\%) 
Berdasarkan hasil pengamatan uji $\mathrm{pH}$ dari masing-masing sedian selama penyimpanan 4 minggu pada suhu ruang, nilai $\mathrm{pH}$ di nyatakan dalam range $\mathrm{pH}$ normal kulit yaitu 5,0 - 6,8. Pengukuran $\mathrm{pH}$ bertujuan untuk mengetahui apakah sediaan yang dihasilkan dapat diterima $\mathrm{pH}$ kulit atau tidak, karena hal ini berkaitan dengan keamanan dan kenyamanan sediaan ketika digunakan (Ardana, dkk., 2015). Kesesuaian pH kulit dengan pH sediaan topical mempengaruhi penerimaan kulit terhadap sediaan. Sediaan topikal yang ideal adalah tidak mengiritasi kulit. Kemungkinan iritasi kulit akan sangat besar apabila sediaan terlalu asam dan kulit akan kering jika terlalu basa (Fauzia, dkk., 2017).

Hasil uji yang diperoleh sediaan gel memenuhi rentang nilai viskositas sediaan gel yang baik. Pemeriksaan viskositas dilakukan dengan menggunakan viscometer Brokfield. Nilai viskositas sediaan gel yang baik yaitu 2000-4000 cps. Viskositas yang terlalu tinggi pada gel akan menyebabkan struktur gel lebih kaku dan zat aktif akan lebih sulit berdifusi melewati matriks gel, sehingga pelepasan zat aktif dari basis gel akan kecil. Viskositas sediaan gel akan mengalami penurunan apabila terjadi peningkatan kosentrasi, sehingga membuat gel semakin encer (Fajrina, 2017).

\section{Pengujian sediaan gel terhadap luka sayat}

Hasil pengamatan uji sediaan terhadap luka sayat yang diberi perlakuan pada mencit dilakukan dengan cara visual, di mana proses penyembuhan berlangsung normal di lihat dari perubahan diameter luka yang semakin mengecil dan persentase diameter pengukuran luka yang semakin meningkat.

Tabel 7. Hasil rata-rata diameter luka pada mencit

\begin{tabular}{|c|c|c|c|c|c|}
\hline \multirow{2}{*}{ Hari } & \multicolumn{5}{|c|}{ Diameter luka (cm) } \\
\cline { 2 - 6 } & $\mathbf{K 1}$ & $\mathbf{K 2}$ & $\mathbf{K 3}$ & $\mathbf{K}$ & $\mathbf{K}$ \\
\hline 1 & 1.5 & 1.5 & 1.5 & 1.5 & 1.5 \\
\hline 2 & 1.34 & 1.32 & 1.3 & 1.3 & 1.48 \\
\hline 3 & 1.12 & 1.1 & 0.96 & 0.84 & 1.02 \\
\hline 4 & 1.02 & 0.76 & 0.74 & 0.64 & 0.76 \\
\hline 5 & 0.92 & 0.62 & 0.56 & 0.56 & 0.62 \\
\hline 6 & 0.74 & 0.56 & 0.52 & 0.5 & 0.6 \\
\hline 7 & 0.66 & 0.4 & 0.4 & 0.38 & 0.32 \\
\hline 8 & 0.64 & 0.32 & 0.26 & 0.3 & 0.34 \\
\hline 9 & 0.58 & 0.24 & 0.24 & 0.26 & 0.3 \\
\hline 10 & 0.48 & 0.24 & 0.2 & 0.22 & 0.28 \\
\hline 11 & 0.4 & 0.22 & 0.2 & 0.16 & 0.12 \\
\hline 12 & 0.38 & 0.22 & 0.16 & 0.12 & 0.12 \\
\hline 13 & 0.34 & 0.14 & 0.16 & 0.08 & 0.12 \\
\hline 14 & 0.28 & 0.12 & 0.16 & 0 & 0.08 \\
\hline 15 & 0.26 & 0.12 & 0.14 & 0 & 0.04 \\
\hline 16 & 0.26 & 0.08 & 0.14 & 0 & 0.04 \\
\hline 17 & 0.24 & 0.08 & 0.08 & 0 & 0.04 \\
\hline 18 & 0.06 & 0.04 & 0.08 & 0 & 0.04 \\
\hline 23 & 0.06 & 0.04 & 0.08 & 0 & 0.04 \\
\hline 21 & 0.06 & 0.04 & 0 & 0 & 0.38 \\
\hline
\end{tabular}

Keterangan : K = Sediaan, 1 (ekstrak 5\%), 2 (ekstrak 7,5\%), dan 3 (ekstrak 10\%), 4 betadin salep, 5 (tanpa ekstrak)

Hasil pengamatan luka terhadap rata-rata penyembuhan diameter luka di dapat pengurangan yang berlangsung cepat yang ditandai dengan penutupan luka semakin berkurang hingga sembuh. Grafik rata-rata persentase penyembuhan luka dapat di lihat pada gambar berikut. 


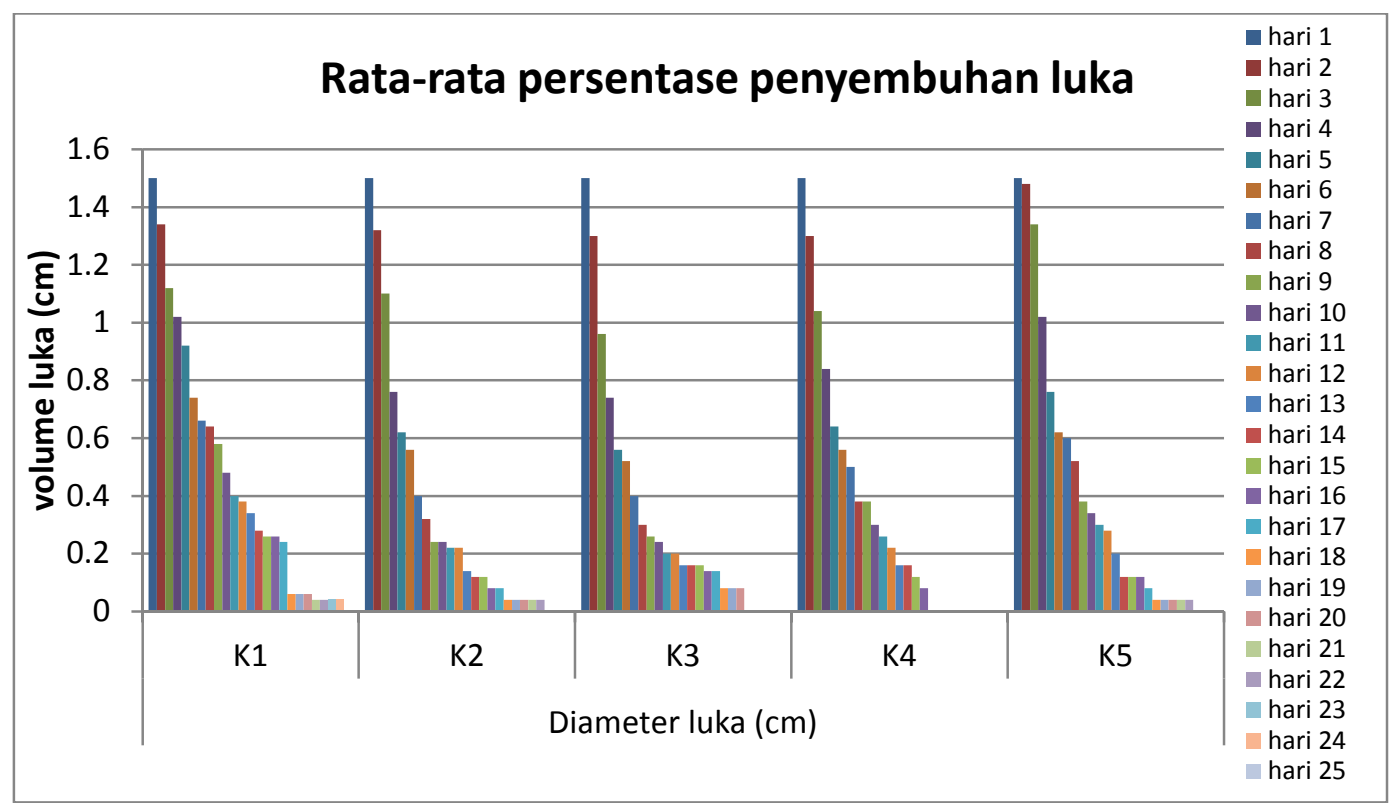

Keterangan : K = Sediaan, 1 (ekstrak 5\%), 2 (ekstrak 7,5\%), dan 3 (ekstrak 10\%), 4 betadin salep, 5 (tanpa ekstrak).

Gambar 2. Grafik hasil rata-rata perhitungan persentase penyembuhan luka

Perbandingan persentase penyembuhan antara kosentrasi gel ekstrak 5\%, 7.5\%, 10\%, tanpa ekstrak dan betadin salep, dapat di lihat peningkatan persentase penyembuhan luka yang semakin meningkat hingga mencapai $100 \%$. Penyembuhan luka di mulai pada hari ke- 8 sampai ke-21 untuk kontrol gel ekstrak $10 \%$. Penyembuhan luka pada hari ke-13 sampai ke-23 untuk gel ekstrak 7.5\% dan tanpa ekstrak. Penyembuhan luka pada hari ke-13 sampai ke-24 untuk betadin salep. Penyembuhan luka pada hari ke-13 sampai ke-25 untuk gel ekstrak 5\%.

Tabel 8. Hasil persentase pengurangan diameter luka

\begin{tabular}{|c|c|c|c|c|c|}
\hline \multirow{2}{*}{ Hari } & \multicolumn{5}{|c|}{ Persentase penyembuhan luka (\%) } \\
\cline { 2 - 6 } & K1 & K2 & K3 & K4 & K5 \\
\hline 1 & 0 & 0 & 0 & 14 & 2 \\
\hline 2 & 11 & 12 & 14 & 31 & 11 \\
\hline 3 & 26 & 27 & 36 & 44 & 32 \\
\hline 4 & 32 & 50 & 51 & 58 & 50 \\
\hline 5 & 39 & 60 & 63 & 63 & 59 \\
\hline 6 & 51 & 63 & 66 & 68 & 60 \\
\hline 7 & 56 & 74 & 74 & 75 & 66 \\
\hline 8 & 58 & 79 & 80 & 75 & 75 \\
\hline 9 & 62 & 84 & 83 & 80 & 78 \\
\hline 10 & 68 & 84 & 84 & 83 & 80 \\
\hline 11 & 74 & 86 & 87 & 86 & 82 \\
\hline 12 & 75 & 86 & 87 & 90 & 87 \\
\hline 13 & 78 & 91 & 94 & 90 & 92 \\
\hline 14 & 82 & 92 & 94 & 92 & 92 \\
\hline 15 & 83 & 92 & 94 & 95 & 92 \\
\hline 16 & 83 & 95 & 94 & 100 & 95 \\
\hline 17 & 84 & 95 & 94 & 100 & 98 \\
\hline 18 & 94 & 98 & 95 & 100 & 98 \\
\hline 19 & 94 & 98 & 95 & 100 & 98 \\
\hline 20 & 94 & 98 & 95 & 100 & 98 \\
\hline 21 & 98 & 98 & 100 & 100 & 98 \\
\hline
\end{tabular}




\begin{tabular}{|c|c|c|c|c|c|}
\hline 23 & 98 & 100 & 100 & 100 & 100 \\
\hline 24 & 98 & 100 & 100 & 100 & 100 \\
\hline 25 & 100 & 100 & 100 & 100 & 100 \\
\hline
\end{tabular}

Keterangan : K = Sediaan, 1 (ekstrak 5\%), 2 (ekstrak 7,5\%), dan 3 (ekstrak 10\%), 4 betadin salep, 5 (tanpa ekstrak)

Hasil persentase perhitungan pengurangan perubahan diameter luka pada luka di dapat efektivitas penyembuhan luka sayat yang sangat baik pada betadin salep sebagai kontrol positif, kemudian untuk sedian gel ekstrak 10\%, ekstrak 7.5\% dan tanpa ekstrak (kontrol negatif), dan ekstrak 5\%. Grafik persentase pengurangan persentase penyembuhan luka dapat di lihat pada gambar berikut.

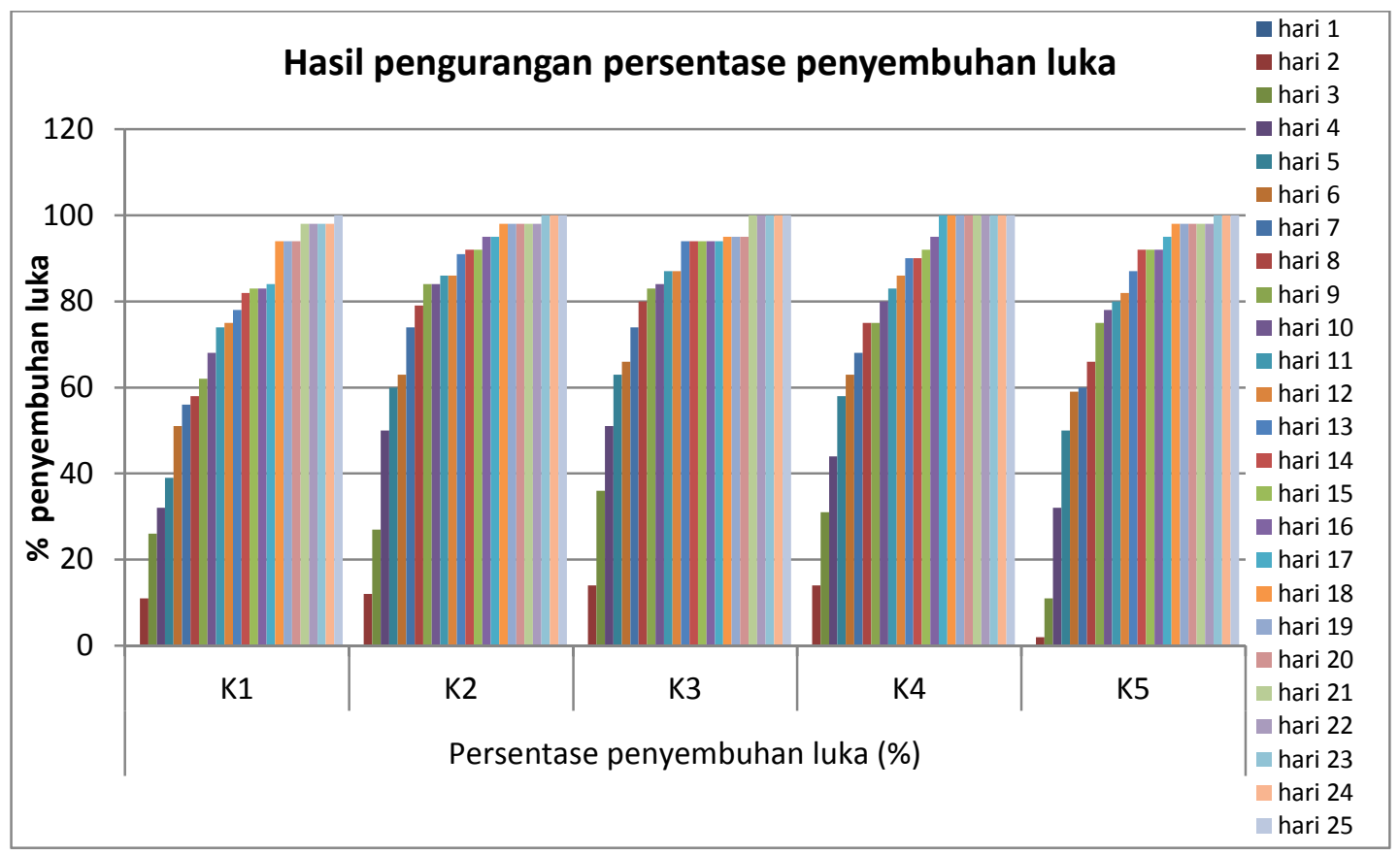

Keterangan : $\mathrm{K}=$ Sediaan, 1 (ekstrak 5\%), 2 (ekstrak 7,5\%), dan 3 (ekstrak 10\%), 4 betadin salep, 5 (tanpa ekstrak).

Gambar 3. Grafik rata-rata persentase penyembuhan luka

Hasil grafik di atas mengambarkan bahwa sampel k4 (betadin salep) lebih cepat dalam rata-rata penyembuhan dibandingkan dengan sediaan gel lainnya. Pada hasil rata-rata mengambarkan keseluruhan hasil dari persentase penyembuhan dan masa sembuh. Maka sediaan betadin salep menjadi persentase pertama penyembuhan dan di ikuti sediaan gel ekstrak 10\%, ekstrak 7.5\%, tanpa ekstrak dan ekstrak 5\%. Namun dalam masa penyembuhan hewan uji pertama kalinya sediaan gel ekstrak $10 \%$ lebih cepat mengalami masa penyembuhan dari semua sediaan uji lainnya.

Hasil statistik dari uji normalitas dan homogenitas dengan uji analisis data varian (ANOVA) menunjukkan hasil data yang terdistribusi normal. Pada pengujian "Kolmogorov-Smirnov test" untuk menentukan normalitas data adalah signifikansi > 0.05 yang berarti data terdistribusi normal dan homogen. Hasil persentase penyembuhan antara sedian gel ekstrak 5\%, 7.5\%, 10\%, tanpa ekstrak dan betadin salep, dapat di lihat peningkatan signifikan persentase penyembuhan luka yang semakin meningkat hingga mencapai $100 \%$.

\section{Kesimpulan}

Ekstrak etanol kacang hijau (Vigna radiata L.) memiliki aktivitas antioksidan dengan nilai $\mathrm{IC}_{50}$ sebesar 129,09 ppm yang secara spesifik tergolong antioksidan dengan kemampuan sedang karena bernilai 100-150 ppm. Pembuatan gel ekstrak etanol kacang hijau (Vigna radiata L.) menunjukkan hasil evaluasi sedian yang stabil. Hasil pengujian organoleptik menunjukkan tidak ada perubahan warna, bentuk, bau dan rasa. Hasil pengujian homogenitas, $\mathrm{pH}$, dan viskositas sedian selama 4 minggu menunjukkan nilai yang stabil dengan tidak terjadi perubahan yang signifikan selama pengujian. Hasil persentase perhitungan pengurangan perubahan diameter pada luka sayat di dapat efektivitas penyembuhan luka sayat yang sangat baik pada betadin salep sebagai kontrol positif, kemudian untuk sedian gel ekstrak 10\%, ekstrak 7.5\% dan tanpa ekstrak (kontrol 
negatif), dan ekstrak 5\%. Pada sediaan gel ekstrak 10\% lebih cepat mengalami penyembuhan dari pada pembanding (sediaan betadin salep) menyebabkan sediaan gel lebih maksimal untuk penyembuhan luka sayat.

\section{Saran}

Disarankan kepada peneliti selanjutnya, untuk mencoba memformulasikan kacang hijau (Vigna radita L.) dalam bentuk sediaan lain, misalnya salep, lotion atau krim, dan untuk lebih mengetahui efek farmakologi lainnya dari senyawa metabolit ekstrak kacang hijau (Vigna radiata L.).

\section{DAFTAR PUSTAKA}

Ardana, M., Aeyni, V., \& Ibrahim, A. (2015). Formulasi dan optimasi basis gel HPMC (Hidroxy Propyl Methyl Cellulose) dengan berbagai variasi kosentrasi . J. Trop. Pharm. Chem. Vol 3 (2).

Fauziah, S. R., Wangi TW, M. A., \& Sulastri, I. (2017). Uji efektivitas anti-inflamasi salep ekstrak rimpang kencur(Kaempferia galanga L.) terhadap luka sayat pada tikus jantan. Jurnal Sains dan Ilmu Farmasi. Vol. 2 (3).

Fajrina, A. (2017). Formulasi sediaan gel ekstrak etanol daun Jambu bol (Syzgium malaccense L. Merr \& Perry) Sebagai pengobatan luka sayat. Skripsi. Sumatera Utara: Universitas Sumatera Utara.

Mayasari, U., Laoli, M. T. (2018). Karakterisasi simplisia dan skrining fitokimia daun jeruk lemon (Citrus lemon (L.) Burn.f). Klorofil. Vol.2 (1).

Moniharapon, P. J., Queljoe, E. D., \& Simbala, H. (2016). Identifikasi fitokimia dan uji aktivitas antioksidan ekstrak etanol tauge (Phaseolus radiatus L.). Jurnal Ilmiah Farmasi - UNSRAT . Vol. 5 (4).

Ningsih, S., Patusuri, A. A., \& Amalia, K. N. R. (2015). Uji efek penyembuhan gel ekstrak daun jarak merah (Jatropha gossypifolia Linn.) terhadap luka sayat pada kelinci (Oryctolagus cuniculus). JF FIK UINAM. Vol.3 (3).

Novidiyanto, Farmawati, A., \& Lestari, L. A. (2016). Pengaruh pemberian kecambah kacang hijau (Phaseolus radiatus L.) terhadap kadar malondealdehid (MDA) plasma dan jaringan hati tikus Sprague Dawley yang diberi pakan lemak tinggi. Jurnal Gizi Klinik Indonesia, Vol 13 (2). 